\title{
The Geology of Dumne Area in Southeastern Hawal Massif, Northeastern Nigeria
}

\author{
Julius B. Kwache ${ }^{1}$, Eyo E. Ntekim ${ }^{2}$ \\ ${ }^{1}$ Department of Regional Geology, Nigerian Geological Survey Agency, PMB 2011, Yola, Adamawa State, Nigeria \\ ${ }^{2}$ Department of Geology, Modibbo Adama University of Technology, PMB 2076, Yola, Adamawa State, Nigeria
}

\begin{abstract}
Dumne area, situated at the southeastern part of Hawal Massif, Northeastern Nigeria is underlain by gneisses, migmatites, Older Granites and Tertiary basalts with granite gneiss dominating. Both granites and gneisses contain mainly feldspars, hornblende, biotite, quartz and numerous opaque minerals and high silica (57.20 wt \% and 60.50 wt \%) and alumina (9.19 wt \% and 7.40 wt \%). Basalts have high concentration of $\mathrm{Fe}_{2} \mathrm{O}_{3}(11.08 \mathrm{wt} \%)$ contents, granites have high alkalis $(\mathrm{Na}+\mathrm{K})$ contents while the mean concentration of trace elements is generally low in all the rocks. The mineralogical and geochemical compositions of the gneisses and granites have strong similarity. The outcrops show gradational contact with each other but exhibit sharp contact with the surrounding sedimentary cover depicting igneous origin for the entire rock suite. The minerals exhibit strain and deformational features depicting a highly deformed rock suite.
\end{abstract}

Keywords: Benue Trough; Dumne; Igneous; Massif; Nigeria.

\section{Introduction}

Dumne area is situated at the southeastern tip of Hawal Massif, Northeastern Nigeria. It lies within the geographical coordinates, northing's $9^{0} 45^{\mathrm{I}}$ and $9^{0} 51^{\mathrm{I}}$ and easting's $12^{0} 15^{\mathrm{I}}$ and $12^{0} 25^{\mathrm{I}}$ (Fig. 1). It is bounded in the west and south by the Gongola and Yola arms of the Benue Trough. The geology of the area still remains largely unknown as no detail work has been done to delineate and describe the different rock units in the area. However, previous workers such as [1], [2], [3], [4], [5], [6], [7] and [8] reported that southern Hawal massif area consists of gneiss, granite gneiss, granites and some minor rocks such as dolerite, aplite and pegmatite. Ref [9] and [10] stated that the basement complex rocks in Hawal and Adamawa Massifs are part of the extension of the Cameroon uplifts into Northeastern Nigeria. Ref [11] reported that the basement complex rocks in this area are believed to be polycyclic having been affected by various tectonic events with different intensities resulting in different episodes of folding, faulting and granitic emplacement along the linear shear zones from Archean to late Proterozoic (Pan-African).

\section{Methods and Materials}

Road, stream and compass traversing were used to map all the outcrops in the area. Representative rock samples were collected for Petrographic studies and chemical analysis. Chemical analyses of the samples were done using Atomic Absorption Spectrometric (AAS) method at the National Geosciences Laboratory Research Center, Kaduna, Nigeria. Thin sections of five chosen representative samples were studied using Leica 24 microscope with x10 magnification at American University of Nigeria, Yola.

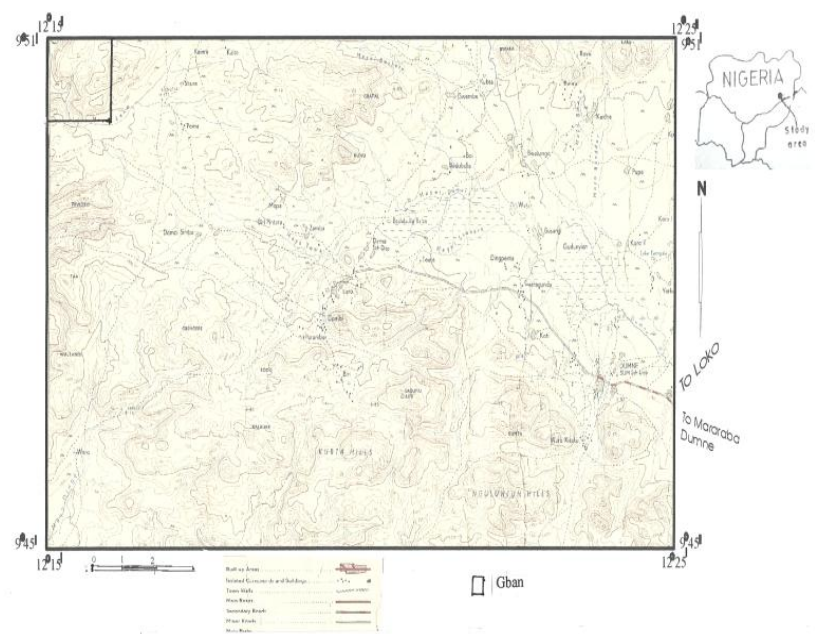

Figure 1: Topographic map of the study area

\section{Results}

\subsection{Lithologic Units}

Three groups of rock units were encountered in the area. These include the major rock units, which consists of gneisses, migmatites, granites and basalts outcropping mainly as a range of hillocks and in some parts overlain by Tertiary alluvium; the minor rock units comprising the intermediate intrusive such as pegmatite, aplite, dolerite, quartz veins and mylonite; and lastly the alluvium, which is confined to the banks of streams and rivers (Fig. 2). 


\section{International Journal of Science and Research (IJSR) ISSN (Online): 2319-7064}

Index Copernicus Value (2013): 6.14 | Impact Factor (2014): 5.611

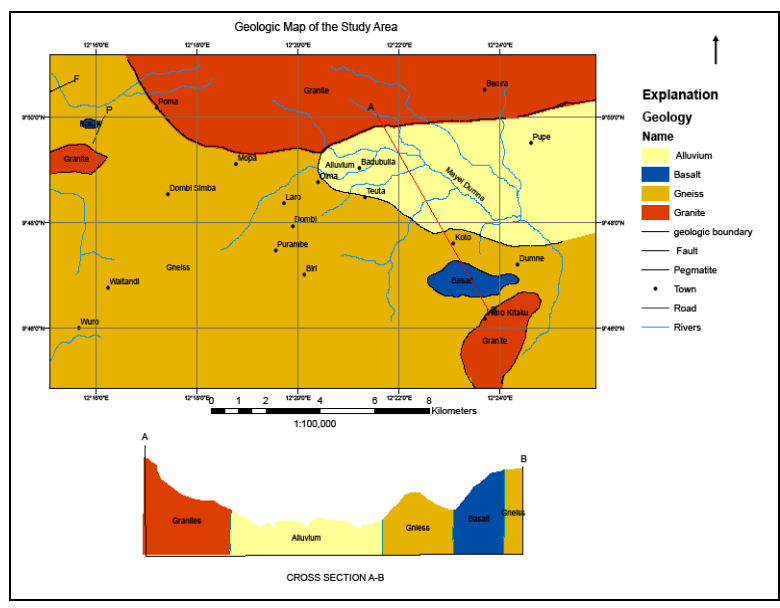

Figure 2: Geologic map of Dumne

\subsubsection{Major Rock Units}

\subsubsection{Gneisses}

The rocks generally outcrop sandwiched between migmatites and granites at Dumne, Koti, Waltandi, Biri, Wuro Kitaku, Dombi and Dirma areas. Granite gneisses are the most dominant gneissic rocks and were observed at Waltandi, old Prambe, Biri and Zamba areas. The granitic nature sometimes grade into dioritic composition with increasing mafic minerals, especially biotite and hornblende as seen west and south of Dirma and Dombi-Simba, hence are named biotite-hornblende gneisses. In some places, especially towards the base of the hills, the rocks grade into migmatitic gneiss. They also exhibit varying degrees of trend of weak foliation marked by varied sizes, amounts and orientation of feldspars porphyroblasts. The porphyroblasts are sometimes numerous and moderately large (between 4 $\mathrm{mm}$ and $1.0 \mathrm{~cm}$ in width and 1 to $1.5 \mathrm{~cm}$ long), lineated, augen-shaped or may show small equidimensional rhombic grains with less pronounced lineation as observed at Dirma, Laro and old Prambe. In some areas, the rocks are banded (for example at Koti, Dirma and Waltandi), and in others, especially those with increased biotite content, no distinctive banding is observed. They exhibit variable colours due largely to the nature and proportion of the feldspars and mafic minerals, mainly biotite and hornblende. Texturally, the rocks are coarse grained and consists of alternating bands of mafic and felsic minerals with abundant quartz and orthoclase feldspar contents. They are variedly invaded by pegmatite vein, as seen close to Gban and healed fractures, which are evident of recrystallization. Parts of many outcrops, especially portions on the slopes, have undergone spheroidal weathering as seen south of Dumne, Zamba, Laro and Woro.

\subsubsection{Migmatites}

Migmatites occur in varying composition and texture. They are medium to coarse grained and weakly foliated with regular or discontinuous and sometimes folded bands as observed south of Dumne. The banding ranges from $4 \mathrm{~mm}$ across to $10 \mathrm{~cm}$ and are generally conformable with the regional structural trend. Two major types of migmatites, the veined and the agmatite types outcrop in the area. In the veined, the palesomes are invaded by numerous thin metasome bands (mainly quartzitic and quartzo-felsdpathic veins) along the weak foliation planes as observed at
Dumne, Koti and Laro. The agmatites show characteristic network of aplite and pegmatite veins dissecting the palesomes into regular blocks as outcropped at Woro, Waltandi and Dombi. Most of the veins are undeformed. The rocks were probably formed by late injection of quartzo-felsdpathic rich acid materials into the gneissic host rocks.

\subsubsection{Older Granites}

Rocks of this suite include granodiorites, porphyritic and coarse grained granites. The granodiorites crop out more conspicuously at the base of slopes of the small isolated hills, associated with porphyritic granites as observed at Laro, Biri Pintara, old Prambe, Zamba, Dirma and east of Waltandi. Most of them occur as in-situ boulders of different sizes ranging from $50 \mathrm{~cm}$ to as big as $20 \mathrm{~m}$; but some occur in a hillock range showing gradational contact with the porphyritic granites and sharp contact with gneisses. The granodiorites are mostly porphyritic but sometimes are medium to coarse grained and are affected by extensive spheroidal weathering as seen at Dumne, Koti, Biri and Gbengere hills. Numerous large phenocrysts of orthoclase feldspar of different sizes ranging from $5 \mathrm{~mm}$ to $3 \mathrm{~cm}$ are scattered within the rock fabric. The porphyritic granites outcrop in many locations in the mapped area covering most relief peaks above $365.8 \mathrm{~m}$ contour line south of Dumne and Gban with its scattered boulders on the slopes and the base of hills. The rocks contain large grains of microcline, hornblende and biotite set in a coarse matrix of quartz and subordinate oligoclase together with flakes of muscovite and biotite. Most minerals, except biotite exhibit strain features marked by E-W and N-S trending striations in the feldspar grains. Thus, the biotite grains are considered to be postdeformational. They are affected by spheroidal weathering and are invaded by N-S trending pegmatitic and aplitic veins. The coarse grained granites occur in various locations closely associated with the migmatites and gneisses in the low relief ranges. They occur mainly as sizeable plutons and show lithological variations with aplite. Exposures of both types were distinctly observed at Shure, Poma, Kubta, Bwara and north of Mopa areas. The rock is crystalline, coarse grained and compact, with few distinct northerly fractures. However, numerous rehealed fractures of aplitic and pegmatitic compositions crisscross the rock surface. The feldspar porphyblasts, which vary from pinkish microcline to white oligoclase, are fairly aligned conformable to the $\mathrm{N}$ $\mathrm{S}$ regional structural trend. Quartz veins also crosscuts the rocks.

\subsubsection{Basalts}

Two types of basalts were encountered in the mapped area. These are the non-vesicular and the vesicular. They occur in boulders of different sizes ranging from $14 \mathrm{~cm}$ to about $4 \mathrm{~m}$. They are fine grained, black and contain some grains of olivine phenocrysts scattered within the matrix of the rock. The vesicular basalt type occurs at the base of gneisses south of Dumne. It ranges in size from $30 \mathrm{~cm}$ to about $60 \mathrm{~cm}$. The vesicles range between $2 \mathrm{~mm}$ to $4 \mathrm{~mm}$ in diameter and are randomly distributed within the rock. The non-vesicular basalts occur as ridges south of Dumne and south of Gban. Relics of basaltic flows, represented by boulders and black soil are found in almost all the drainage channels and lowlying plains.

\section{Volume 4 Issue 11, November 2015}




\section{International Journal of Science and Research (IJSR) \\ ISSN (Online): 2319-7064}

Index Copernicus Value (2013): 6.14 | Impact Factor (2014): 5.611

\subsubsection{Minor Rock Units}

\subsubsection{Pegmatite}

Pegmatite composed of microcline and quartz minerals were observed in all the rock units. They vary in size from lenses and veinlets of $20 \mathrm{~cm}$ to bodies up to $2 \mathrm{~m}$ wide and over 100 $\mathrm{m}$ long. Generally, pegmatites are wide spread in the western part of the area especially around Waltandi, southeast of Gban and Dombi with an average trend of $022^{0}$ and dip of $65^{\circ} \mathrm{NW}$ respectively.

\subsubsection{Dolerite}

Dolerite dykes, the youngest member of the basement complex occur as tabular and jointed unmetamorphosed bodies crosscutting foliation in gneisses and Older granites in Waltandi, Gban, Shure and Dumne. The dolerite dykes ranges from $6 \mathrm{~cm}$ to $1.5 \mathrm{~m}$ wide and over $50 \mathrm{~m}$ long. The rock is generally black and fine grained, with some pale green spots of olivine when observed in the hand specimen.

\subsubsection{Aplite}

They occur as granitic intrusions in the gneisses and the granites. They are characteristically fine grained, light coloured and granitic in composition. The widths range from $25 \mathrm{~cm}$ to about $1 \mathrm{~m}$ and over $40 \mathrm{~m}$ long as observed between Dumne and Koti.

\subsubsection{Quartz Veins}

The quartz veins and lenses occur crisscrossing the basement rocks especially the granites. They are small, varying in width from $10 \mathrm{~cm}$ to $40 \mathrm{~cm}$ and over $100 \mathrm{~m}$ long and show great irregularities in their form. They sometimes thin-out, widen or bend in their course. Significant among the quartz veins are those at Dumne, Mopa, Shure, Zamba and Dirma.

\subsubsection{Mylonite}

These rock units occur at Gban and Dumne within the gneisses and Older granites. They are brecciated and sheared containing angular fragments produced by the crushing, fracturing and differential movement of the component grains of the pre-existing rocks. At Gban, the rocks are creamy white, fine to medium grained and trends ENE WSW $\left(70^{\circ}\right)$ coinciding with the trend of the Benue Trough. They show some streaky or banded structure which have been pulverized indicating faulting. According to [12], large mylonitic zones or shear belts are usually associated with faulting and fault zones. The recognition of cataclasites (mylonite) zones often lead to the recognition of faults and structural breaks in a region [13].

\subsubsection{Alluvium}

Alluvial deposits of sand, gravel, pebbles and cobbles are mechanically weathered remains derived from bedrock and surrounding hills found along stream and river channels. Exposures of the deposit also outcrop on plains in the northeastern part of the mapped area where farming activities is extensive.

\subsection{Petrography}

Table 1: Average Modal Composition of Rocks in Dumne Area

\begin{tabular}{|c|c|c|c|c|c|}
\hline $\begin{array}{c}\text { Rock } \\
\text { samples / } \\
\text { Minerals }\end{array}$ & $\begin{array}{c}\text { D16 } \\
\text { (Gneiss) }\end{array}$ & $\begin{array}{c}\text { D22 } \\
\text { (Older } \\
\text { Granite) }\end{array}$ & $\begin{array}{c}\text { D2 (Basalt } \\
\text { Vesicular) }\end{array}$ & $\begin{array}{c}\text { D9 } \\
\text { (Basalt } \\
\text { Non- } \\
\text { vesicular) }\end{array}$ & $\begin{array}{c}\text { D8A } \\
\text { (Mylonite) }\end{array}$ \\
\hline Quartz & 44 & 58 & 5 & 4 & 25 \\
\hline Biotite & 9 & 11 & 5 & 3 & 10 \\
\hline Hornblende & 6 & 6 & - & - & 1 \\
\hline Plagioclase & - & 9 & 10 & 9 & 17 \\
\hline Pyroxene & 5 & - & 15 & 14 & - \\
\hline Microcline & 8 & 6 & - & - & 35 \\
\hline $\begin{array}{c}\text { Orthoclase } \\
\text { feldspar }\end{array}$ & 22 & 8 & - & - & 10 \\
\hline Garnet & 2 & - & - & - & - \\
\hline Opaque & 2 & 2 & 20 & 25 & 2 \\
\hline Olivine & - & - & 45 & 44 & - \\
\hline Albite & 2 & - & - & - & - \\
\hline
\end{tabular}

Examination of the slides shows that sample D16 is coarse grained banded gneiss exhibiting alternating bands of mafic and felsic minerals (Fig. 3) while sample D22 is coarse grained granite (Fig. 4). In the coarse grained banded gneiss,

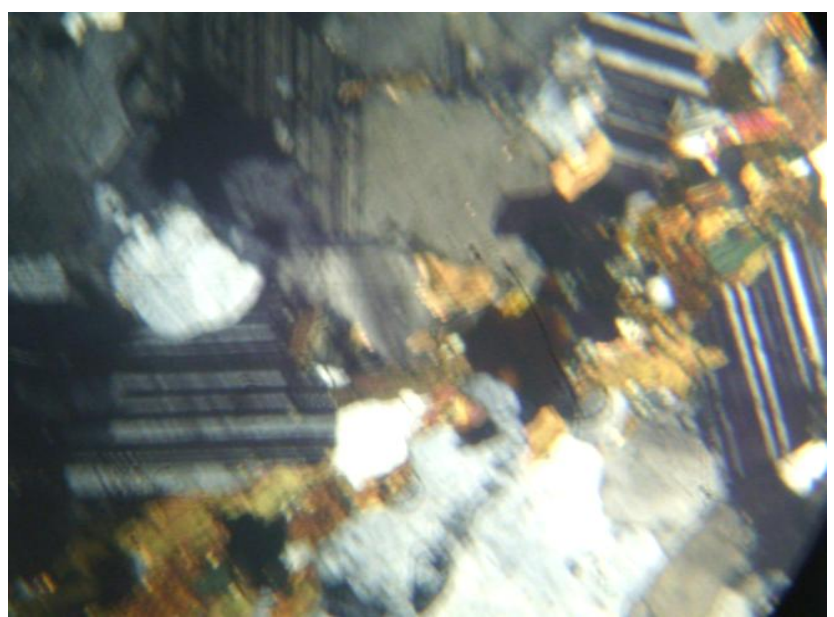

Figure 3: Coarse grained banded gneiss

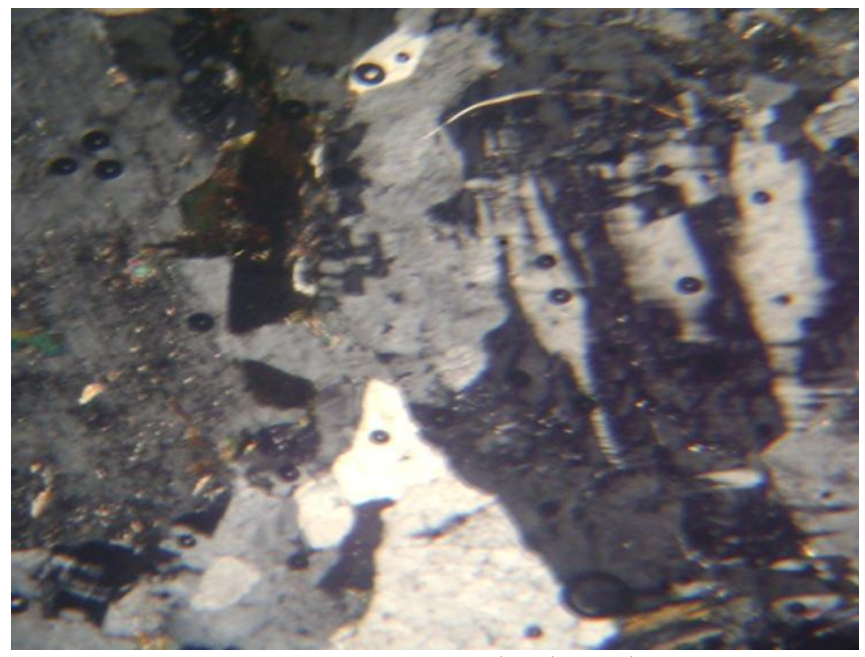

Figure 4: Coarse grained granite

The mafic minerals consist of biotite with hornblende as accessory while the felsic minerals consist mainly of quartz, orthoclase and microcline feldspar. Also garnet minerals

\section{Volume 4 Issue 11, November 2015}




\section{International Journal of Science and Research (IJSR) \\ ISSN (Online): 2319-7064 \\ Index Copernicus Value (2013): 6.14 | Impact Factor (2014): 5.611}

with numerous felsdpathic and hornblende inclusions were observed. The groundmass, which shows foliated texture, is dominated by broken pieces of biotite, quartz and some opaque minerals which contain feldspathic inclusions. The minerals generally show strained features like striation, fractures and disintegration while the biotite has preferred orientation. The marked felsdpathic inclusions in the minerals coupled with the disintegrating and sugary textures of feldspars in the rocks probably depict deformation. Petrologically, the gneisses in Dumne area include; granite gneiss, augen gneiss, agmatite and veined types which conform to [6]. In the coarse grained granite, the rock contains large crystals of quartz and microcline feldspar. The phenocrysts of quartz are anhedral to subhedral. Other minerals in the sample include biotite and hornblende. The ground mass, which shows foliated texture, is dominated by broken pieces of biotite and some quartz. Hornblende and biotite grains are altered and the mineral grains are disintegrated depicting highly deformed rocks [6]. Sample D2 and D9 are vesicular and non-vesicular basalts (Fig. 5 and 6).

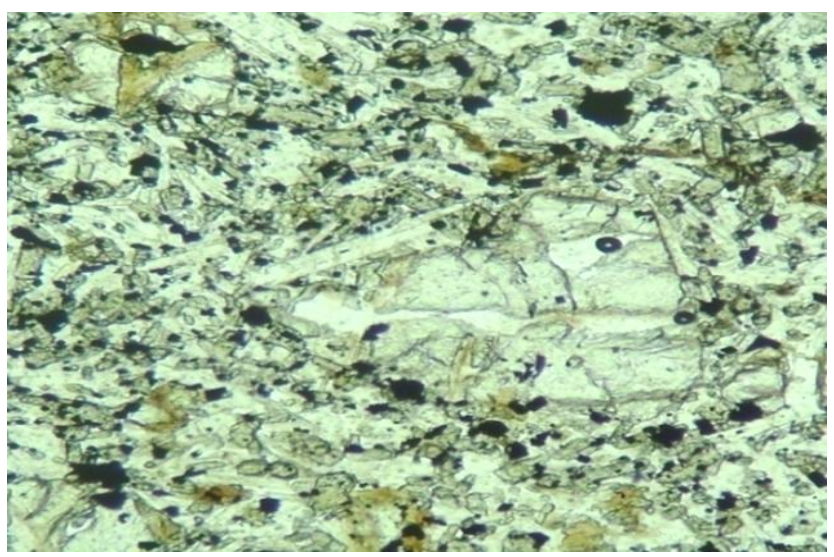

Figure 5: Non-vesicular basalt SE of Gban

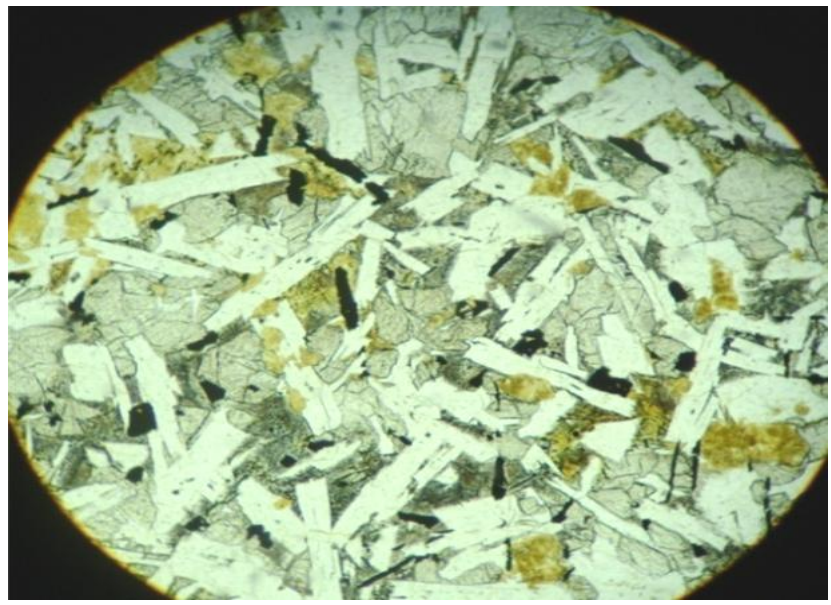

Figure 6: Vesicular basalt at Dumne.

They consist of olivine, pyroxene, plagioclase (labradorite), biotite and numerous opaque minerals. The olivine is sometimes partly altered and contains some voids that are filled with plagioclase mineral grains. The vesicular basalt displays well formed lath structures of pyroxene and plagioclase which have anorthite estimation of An60 (labradorite) and showed some zoning in some places. The grains are larger than those of the non-vesicular basalt.
In the mylonite, the constituent grains of the mylonite matrix dominate the groundmass and commonly appeared ribbonlike with platy fractures characterized by a very close texture with banding. According to [14] this suggests that they have developed as much by ductile deformation as by actual crushing, grinding or milling; the planar structure developed is then appropriately called a flow or fluxion structure. Quartz, microcline and plagioclase are the dominant minerals.

\subsection{Chemical Composition}

Results of the representative samples shows that $\mathrm{SiO}_{2}$ contents is low in the gneisses $(57.20 \mathrm{wt} \%)$ compared to the granites $(60.50 \mathrm{wt} \%)$ and lowest in the basalts $(46.21 \%)$. $\mathrm{Al}_{2} \mathrm{O}_{3}$ is higher in the granites $(9.19 \%)$ compared to gneiss $(7.40 \%)$ while basalts has the highest (13.22\%). $\mathrm{Fe}_{2} \mathrm{O}_{3}$ content is high in the gneisses $(14.54 \mathrm{wt} \%)$ but low in the granites $(3.23$ wt \%) and 11.08 wt \% in the basalts. $\mathrm{CaO}$ contents are $6.59 \mathrm{wt} \%$ in the gneisses, $4.11 \mathrm{wt} \%$ in the granites and $9.45 \%$ in the basalts. The alkali $(\mathrm{Na}+\mathrm{K})$ in the granites are $12.04 \%$, gneisses $6.54 \%$ and $6.95 \%$ in the basalts. Mean concentration of trace elements is generally low in all the rocks. Some REE concentrations of Ce and $\mathrm{Nd}$ are absent in the gneisses while in the granites are 162.82 ppm and 85.73 ppm respectively. Eu is $2072.64 \mathrm{ppm}$ in the gneiss and $259.08 \mathrm{ppm}$ in the granites.

\subsection{Structures}

\subsubsection{Joints.}

Joints in the area are initiated by tectonic activities and trends in different directions (Figures 7and 8). The joints occurred in all the rock units studied with most of them trending WNW - ESE and ENE - WSW. This is consistent with the general trend of the Nigerian basement complex

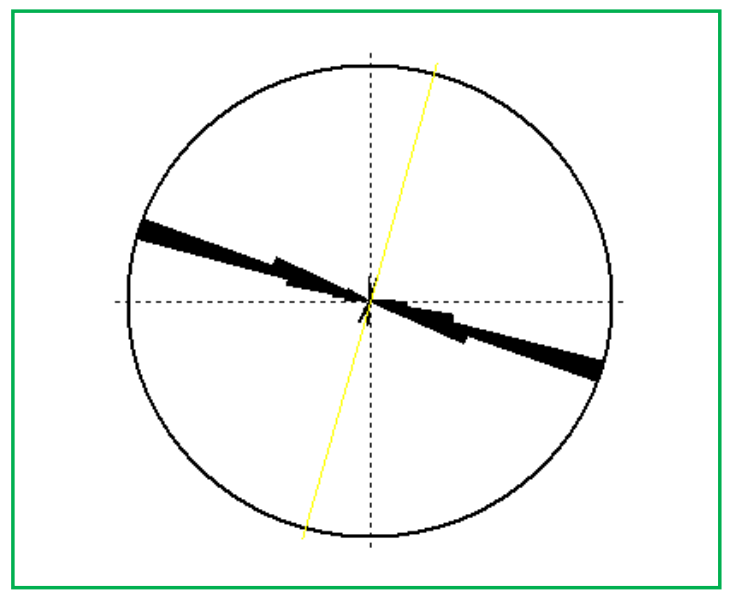

Figure 7: A rose diagram of joints direction at Dumne 


\section{International Journal of Science and Research (IJSR)}

ISSN (Online): 2319-7064

Index Copernicus Value (2013): 6.14 | Impact Factor (2014): 5.611

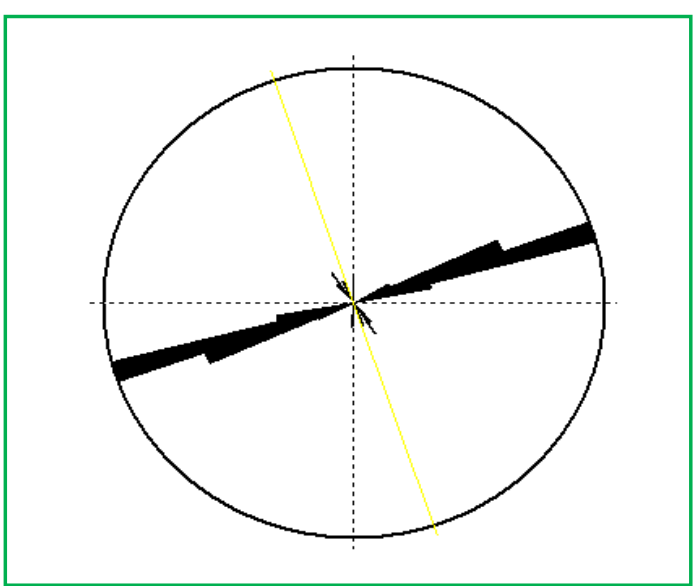

Figure 8: A rose diagram of joints direction at Gban

\subsubsection{Fault}

Fault in the area was recognized based on the occurrences of mylonite at Gban. The fault trends ENE - WSW $\left(070^{\circ}\right)$. Ref [8] identified other faults at Gwaraguda and Dumne on the basis of the orientation of slickenside and rock brecciation, and concluded that the rocks in the area are not only faulted but sheared.

\section{Discussion}

Outcrops of the studied rocks show gradational contact with each other but exhibit sharp contact with the surrounding sedimentary covers. This according to [15] is an evidence of igneous origin for the entire rock suite. The mineralogical and geochemical compositions of the gneisses and the granites have strong similarity as demonstrated on primordial mantle graph after [16] (Fig. 9) and the $\mathrm{CaO}-$ $\mathrm{NaO}-\mathrm{SiO}_{2}$ diagram (fig. 10). Both groups contain mainly feldspars, hornblende,

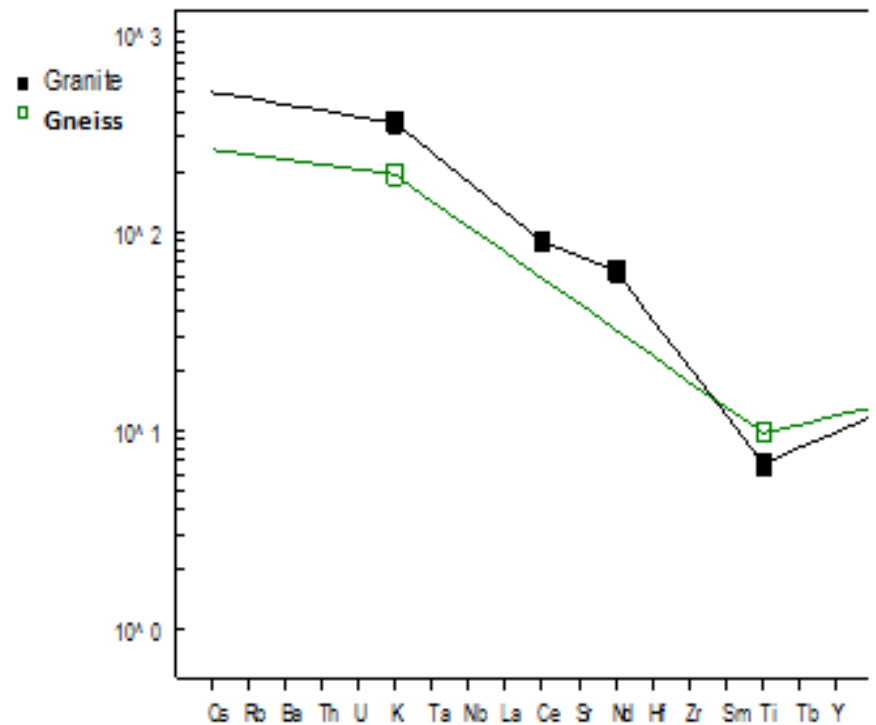

Figure 9: Primordial Mantle after McDonough et. al 1992

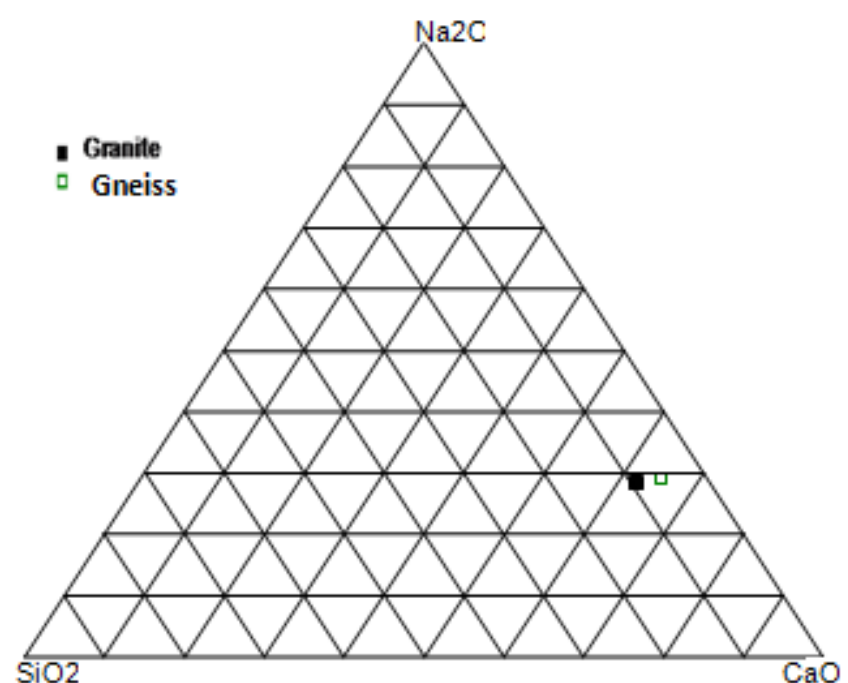

Figure 10: $\mathrm{Plot}$ of $\mathrm{NaO}-\mathrm{SiO}_{2}-\mathrm{CaO}$ diagram

biotite, quartz and numerous opaque minerals. The range of their chemical constituents show averaging high $\mathrm{SiO}_{2}$, but low $\mathrm{Fe}, \mathrm{Ca}$ and alkalis. The high contents of alumina and silica in the gneisses and close parity in values to those of the granites suggests the original rock suite to be granitic in composition. Their geochemical similarity depicts petrogenetic affinity, a relationship that is further confirmed by the close association of the granites with the gneisses and migmatites in the field. The agmatites and veined gneisses probably mark the contact region between the Older granite country rock at the base of relief and their granitic pluton (represented by the granites on the top). The field relationships of the granites to the gneisses (occurring as cover at peak or higher elevations of gneissic hills) suggest anatectic alteration of the older gneissic rocks [4]. The plot of the granitic rock within calc-alkali series fields suggests that the gneiss protoliths were primarily of intermediate composition. Similarly, the plot of granite $(\mathrm{FeO} / \mathrm{FeO}+\mathrm{MgO}$ vs $\mathrm{SiO}_{2}$ ) after ['17] shows that the granite is the S-type. The plot of $\mathrm{SiO}_{2}$ vs $\mathrm{CaO}$ for the gneiss after [18] shows that the gneiss is arkosic. The basalts are olivine normative and the appreciable silica content is typical of a basinite [19]. Occurrence of N-S trending dolerite and pegmatite veins on the outcrops is evident of Pan-African event in the area, during which the anatectic granites were formed

\section{Conclusions}

Granite gneiss constitutes the predominant rocks types in Dumne area of the southern Hawal massif. Other major rocks include granites, migmatites, Older granites and basalts. The rocks are granitic in composition and exhibit close relationship mineralogically, geochemically and in the field. The basalts are basinites.

\section{Acknowledgement}

We acknowledge the assistance of Nigerian Geological Survey Agency and Mr. A.N.Abatcha for supplying the field vehicle for this project. 


\section{International Journal of Science and Research (IJSR) \\ ISSN (Online): 2319-7064}

Index Copernicus Value (2013): 6.14 | Impact Factor (2014): 5.611

\section{References}

[1] M.O Oyawoye. "The Basement Complex of Nigeria". In: African Geology Dessauvagie and Whiteman. (Eds), University of Ibadan 1970. pp 66 - 102, 1972.

[2] P McCurry. (1976): "A general review of the PreCambrian to Lower Paleozoic Rocks of Northern Nigeria": In: Geology of Nigeria, (C.A. Cogbe), (Ed), Rockview (Nigeria) Limited, Jos, Nigeria, pp 13 - 37, 1976.

[3] Reyment, R. A. (1986): Aspects of Geology of Nigeria, Ibadan University Press, Nigeria. 145p, 1986.

[4] M.A Rahaman. Recent advances in the study of the Basement Complex of Nigeria. In: Pre-Cambrian Geology of Nigeria. A publication of Geological Survey of Nigeria, 329p, 1988.

[5] A.C. Ajibade and W.R. Fitches. The Nigerian Precambrian and the Pan-African Orogeny. In: Precambrian Geology of Nigeria. A Publication of Geological Survey of Nigeria, pp $45-53,1988$.

[6] J.L.D Adekeye and E.E Ntekim. "The Geology of Song area in Southern Hawal Massif, N.E. Nigeria”. Zuma Journal of Pure and Applied Sciences 6 (2), pp $145-151,2004$.

[7] J.O Patrick. Geological Mapping of Parts of Song Area, Adamawa State, Northeastern Nigeria. B.Tech. Thesis, Department of Geology, Federal University of Technology, Yola. Unpublished. 67p, 2005.

[8] Bassey, N. E. and Valdon, Y.B. (2011): "Structural Features and Rock Crystal Mineralization in Dumne Area, Hawal Basement Complex, N.E. Nigeria". International Journal of Environmental Science, vol. 7, No. 3. pp $1-8$.

[9] J.B. Kwache. A Magnetic Study of Duhu and its Environs. B. Tech. Thesis, Department of Geology, Federal University of Technology, Yola. Unpublished.69p, 1992.

[10] N.E. Bassey, H.I Ezeigbo. and J,B Kwache. "A Hydrogeological Study of Duhu Area (sheet 135) N.E. Nigeria on the basis of aeromagnetic data". Water Resources Journal, vol. 10, pp 26 - 30, 1999.

[11] P.O.Oluyide. "Structural Trend in Nigerian Basement Complex". In: Precambrian Geology of Nigeria. Oluyide, PO., Mbonu, W.C., Ogezi, A.E., Egbuniwe, I.G., Ajibade, A.C. and Umeji A.C. (Eds)., Geological Survey of Nigeria Publication, pp 93 - 98, 1988.

[12] A.C. Ajibade. "The Origin of the Older Granites of Nigeria: Some evidence from the Zungeru Region". Nigerian Journal of Mining and Geology, 19, pp 223 230, 1982

[13] M. Higgins. "Cataclastic Rocks". Prof. Pap. U.S. Geological Survey, 687, 97p, 1971.

[14] S.R Nockolds, R.W. Knox and G.A. Chinner. Petrology for Students. Cambridge University Press, Cambridge CB2, IRP. 435p 1978.

[15] D.W. Hyndman."Petrology of Igneous and Metamorphic Rocks". McGraw-Hill inc. New-York, 297 p.

[16] McDonough et. al (1992) in M. Petrelli. PetroGraph software version 1.0.5. Department of Earth Sciences, University of Perugia, Italy 2005.
[17] Frost et. al (1997) in M. Petrelli. PetroGraph software version 1.0.5. Department of Earth Sciences, University of Perugia, Italy, 2005

[18] Brown et. al (1979) in M. Petrelli. PetroGraph software version 1.0.5. Department of Earth Sciences, University of Perugia, Italy, 2005.

[19] A. Streckeisen.: Classification and Nomenclature of Igneous Rocks. Neves Jahrb. Mineral Abhandl., 107, pp. $144-240,1967$ 